\title{
Revision of the genus Cuvierina Boas, 1886 based on integrative taxonomic data, including the description of a new species from the Pacific Ocean (Gastropoda, Thecosomata)
}

\author{
Alice K. Burridge ${ }^{\mathrm{I}, 2}$, Arie W. Janssen', Katja T.C.A. Peijnenburg ${ }^{1,2}$ \\ I Naturalis Biodiversity Center, P.O. Box 9517, 2300 RA Leiden, The Netherlands 2 Institute for Biodiversity \\ and Ecosystem Dynamics (IBED), University of Amsterdam, P.O. Box 94248, 1090 GE Amsterdam, The \\ Netherlands
}

Corresponding author: Alice K. Burridge (akburridge@yahoo.co.uk)

Academic editor: N. Yonow | Received 30 July 2016 | Accepted 10 September 2016 | Published 27 September 2016

http://zoobank.org/32AEE355-D6DA-45DE-98D8-C27654903E34

Citation: Burridge AK, Janssen AW, Peijnenburg KTCA (2016) Revision of the genus Cuvierina Boas, 1886 based on integrative taxonomic data, including the description of a new species from the Pacific Ocean (Gastropoda, Thecosomata). ZooKeys 619: 1-12. doi: 10.3897/zookeys.619.10043

\begin{abstract}
Shelled pteropods (Gastropoda, Thecosomata, Euthecosomata) are a group of holoplanktonic gastropods that occur predominantly in the surface layers of the world's oceans. Accurate species identifications are essential for tracking changes in species assemblages of planktonic gastropods, because different species are expected to have different sensitivities to ocean changes. The genus Cuvierina has a worldwide warm water distribution pattern between $-36^{\circ} \mathrm{N}$ and $-39^{\circ} \mathrm{S}$. Based on an integrative taxonomic approach combining morphometric, genetic, and biogeographic information, the two subgenera of Cuvierina, Cuvierina s. str. and Urceolarica, are rejected. A new species is introduced: Cuvierina tsudai sp. n., which has to date been considered the same species as Cuvierina pacifica. Cuvierina tsudai sp. n. is endemic to the Pacific Ocean and is characterised by a shell height of 7.2-8.0 mm, a moderately cylindrical shell shape, the absence of micro-ornamentation and a triangular aperture. Cuvierina pacifica is restricted to the centre of the oligotrophic southern Pacific gyre, has a shell height of 6.6-8.5 mm, a more cylindrical shell shape, no microornamentation and a less triangular aperture than C. tsudai sp. $\mathbf{n}$.
\end{abstract}

\section{Keywords}

Integrative taxonomy, DNA barcoding, geometric morphometrics, pteropods, biogeography

Copyright Alice K. Burridge et al. This is an open access article distributed under the terms of the Creative Commons Attribution License (CC BY 4.0), which permits unrestricted use, distribution, and reproduction in any medium, provided the original author and source are credited. 


\section{Introduction}

Pteropods are holoplanktonic heterobranch gastropods classified in a superorder comprised of the orders Thecosomata and Gymnosomata, commonly referred to as "sea butterflies" and "sea angels", respectively (Lalli and Gilmer 1989, Pierrot-Bults and Peijnenburg 2015). The order Thecosomata consists of Euthecosomata that have sinistrally coiled or straight, bilaterally symmetrical shells, and Pseudothecosomata that have either sinistrally coiled shells, an internal gelatinous pseudoconch, or are shell-less in the adult stage (Meisenheimer 1905, Tesch 1913). Pteropods play an important role in marine food webs (Jörger et al. 2010), and although most species occur in warm tropical and subtropical waters, the highest abundances have been observed for some (sub) polar cold water species (Bé and Gilmer 1977, Van der Spoel and Heyman 1983, Bednaršek et al. 2012, Burridge et al. 2016). Because of their thin-walled, aragonite shells, euthecosomes are exceptionally vulnerable to the effects of ocean acidification (e.g., Fabry et al. 2008, Bednaršek and Ohman 2015, Gattuso et al. 2015, Moya et al. 2016).

The genus Cuvierina is a remarkable group of shelled pteropods with relatively large (5.1-11.1 mm), straight, bottle-shaped shells (Janssen 2005). Ever since Cuvieri$n a$ was described as a mollusc genus (as Cuvieria Rang, 1827, emended by Boas 1886), it has often been considered to consist of a single species, C. columnella (Rang, 1827), the type species of the genus by monotypy. The first taxonomic division within the genus came with the description of a second Cuvierina species, introduced as Cuvieria urceolaris (Mörch, 1850), but in later literature it was often interpreted as a form or subspecies of C. columnella (e.g., Tesch 1913, Van der Spoel 1967, Rampal 1975). A third form, Cuvierina columnella f. atlantica, was described by Van der Spoel (1970), and validated as a taxon of the species group by Bé et al. (1972). Bé and Gilmer (1977) interpreted the morphological differences between the three taxa as infraspecific variability. Contrarily, Rampal (2002) distinguished these taxa as independent species but introduced the taxon C. spoeli to replace the taxonomically invalid Cuvierina columnella f. atlantica. Because the holotype of $C$. spoeli was from the Indian Ocean, where C. atlantica is absent, it rather represented $C$. columnella and was rejected as a valid species by Janssen (2005). Two further extant species, C. cancapae and C. pacifica, were described by Janssen (2005).

According to the most recent taxonomic revision of Cuvierina, five extant species were assigned to two subgenera based on shell morphology and supposed lineages of fossil occurrences since the early Miocene (Janssen 2005, 2006). The subgenus Cuvierina s. str. consisted of C. atlantica, C. columnella, and C. pacifica, which are characterised by relatively slender, cylindrical shells, triangular rather than kidneyshaped apertures and the presence ( $C$. columnella) or absence ( $C$. atlantica, $C$. pacifi$c a)$ of micro-ornamentation. Two geographical varieties were recognised within $C$. pacifica, one from the North Pacific and the other from the South Pacific, but were not formally introduced as new species. The subgenus Urceolarica, containing C. cancapae and $C$. urceolaris, is characterised by more inflated, bottle-shaped rather than 
cylindrical shells, pronounced micro-ornamentation, and kidney-shaped rather than triangular apertures.

All extant Cuvierina species are restricted to the surface layers of tropical and subtropical waters from $-45^{\circ} \mathrm{N}$ to $-40^{\circ} \mathrm{S}$. In the Atlantic Ocean, C. atlantica occurs in the subtropical gyres and $C$. cancapae is found in tropical waters. In the Indian Ocean, $C$. columnella is found in the southern subtropical zone and C. urceolaris occurs in tropical waters and further south along Madagascar towards South Africa. Cuvierina columnella and C. urceolaris also occur in the Pacific Ocean along with C. pacifica (Janssen 2005, Burridge et al. 2015).

Burridge et al. (2015) examined the diversity, distribution, and evolution of $\mathrm{Cu}$ vierina taxa using integrative geometric morphometric, molecular, and biogeographic methods. They confirmed that the five species described for Cuvierina species have significantly different shell shapes and that $C$. pacifica consists of two disjunct morphometric groups, registered as $C$. pacifica $\mathrm{N}$ and $C$. pacifica $S$ in their study. Three genetic lineages were distinguished based on mitochondrial Cytochrome Oxidase I DNA: the Atlantic lineage with $C$. atlantica and $C$. cancapae, the Indo-Pacific lineage with $C$. columnella, $C$. urceolaris, and $C$. pacifica $\mathrm{N}$, and the South Pacific lineage with $C$. pacifica $\mathrm{S}$. A new taxonomic description of $C$. pacifica $\mathrm{N}$ is required because the holotype of $C$. pacifica has the shell shape of C. pacifica S.

Based on the findings of Janssen (2005) and the integrative approach of Burridge et al. (2015) the taxonomy of the genus Cuvierina is revised. The subgenera Cuvierina s. str. and Urceolarica are rejected, a new species, $C$. tsudai, is described from the Pacific Ocean, and the species description of C. pacifica is restricted to the South Pacific lineage. A taxonomic key is provided for the identification of Cuvierina species.

\section{Methods}

Two approaches were used to distinguish between $C$. tsudai and C. pacifica based on differences in shell shape. First, simple measurements of shell height and width, aperture diameters, and position of maximum shell width as applied to museum specimens by Janssen (2005) were used to distinguish between $C$. tsudai and C. pacifica. Second, geometric morphometric data of shell shapes in ventral and apertural orientations were used for 168 adult specimens of Cuvierina that were registered as C. pacifica $\mathrm{N}$ or $C$. pacifica $S$ in Burridge et al. (2015). The specimens corresponded to museum specimens as identified and measured by Janssen (2005, $\mathrm{N}=92$ ), additional museum specimens $(\mathrm{N}=24)$, and recently collected fresh specimens $(\mathrm{N}=52)$. Geometric morphometric methods consisted of digitising shell outlines using tpsDig and tpsUtil (Rohlf 2006) to contain 76 ventral and 37 apertural semi-landmarks per shell, after which a generalised least square Procrustes superimposition was applied (GLS, Kendall 1977 in Zelditch et al. 2004) to rotate, translate, and scale the semi-landmark coordinates. A subsequent thin-plate spline (TPS) analysis (e.g., Zelditch et al. 2004) provided centroid sizes, a size measure depending on surface area, and multiple relative 
warp axes per specimen, containing information on shape. To describe the new species $C$. tsudai as well as to reject the validity of the Cuvierina subgenera, Cytochrome Oxidase I mitochondrial (COI) DNA and 28S ribosomal DNA sequence data from Burridge et al. (2015) were used.

\section{Results and discussion}

\section{Distinction between Cuvierina tsudai and C. pacifica}

Cuvierina tsudai and C. pacifica are similar in size but have different shell shapes, COI $\mathrm{mtDNA}$ and $28 \mathrm{~S} \mathrm{rDNA}$. Because of their Pacific distributions and similarities in shell size, $C$. tsudai and $C$. pacifica have to date been considered the same species. Although Janssen (2005) demonstrated their presence as morphological varieties within C. pacif$c a$, the congruence between morphometric and genetic differentiation supports the separation into two species (Figs 1A-J and 2, fig. 4 in Burridge et al. 2015). Shell heights of $C$. tsudai specimens are between 7.2 and $8.8 \mathrm{~mm}$, showing a large overlap with $C$. pacifica, which measures between 6.6 and $8.5 \mathrm{~mm}$ (Janssen 2005). However, in terms of shell shape, C. pacifica and C. tsudai are significantly different (fig. 29 lower left in Janssen 2005, Burridge et al. 2015). The shell of $C$. tsudai is wider (more inflated) than the slender and more cylindrical C. pacifica (Fig. 2). Cuvierina pacifica has a larger height/width-ratio between 3.25 and 3.96 (mean 3.50) compared to $C$. tsudai, which has a ratio between 2.77 and 3.46 (mean 3.14). The position of maximum shell width is located at $34-45 \%$ (mean $40 \%$ ) of the shell height from the septum upwards for C. pacifica and at 33-42\% (mean 37\%) for C. tsudai (Janssen 2005). The aperture of $C$. tsudai is wider, more triangular and more concave on the ventral side than in $C$. pacifica. The overall shape variation is larger for C. tsudai than for C. pacifica (Fig. 2). The average pairwise genetic distance of COI mtDNA (658bp fragment) between $C$. tsudai $(\mathrm{N}=16)$ and $C$. pacifica $(\mathrm{N}=43)$ is $4.5 \%$. The genetic variation of COI within C. tsudai is $1.6 \%$ compared to $0.8 \%$ within C. pacifica. The $28 \mathrm{~S}$ rDNA fragment (965bp) of C. tsudai differs at least at one position compared with other Cuvierina species, except for C. columnella (Burridge et al. 2015).

The larger genetic and shell shape variation for C. tsudai compared to C. pacifica coincides with a much larger Pacific distribution and lower ecological specificity of C. tsudai. Cuvierina pacifica is restricted to the centre of the oligotrophic southern Pacific gyre and occupies a more specialised ecological niche based on ecological niche modelling (ENM) than C. tsudai (Burridge et al. 2015). This study used presence-only data and six uncorrelated environmental parameters, of which ocean surface temperature and chlorophyll a concentration were the most important. The distribution of $C$. tsudai was mostly explained by maximum monthly sea surface temperatures (SST) and near-surface chlorophyll a concentrations (both 30.8\%). The distribution of $C$. pacifica was best explained by low maximum monthly chlorophyll $a$ concentrations (57.1\%). 


\title{
Description of Cuvierina tsudai sp. n.
}

\author{
Superfamily Cavolinioidea Gray, 1840 \\ Family Cuvierinidae Gray, 1840 \\ Genus Cuvierina Boas, 1886 ( = replacement name for Cuvieria Rang, 1827 non \\ Lesueur \& Petit, 1807, pl. 30 (Coelenterata)
}

Type species. Cuvieria columnella Rang, 1827, p. 323, pl. 45 figs 1-3, by monotypy.

\section{Cuvierina tsudai sp. $\mathrm{n}$.}

http://zoobank.org/B33A28E9-BCDE-4F2B-9349-F3E18CCD87BE

Cuvieria columnella Rang, 1827: 323 (partim).

Cuvierina columnella: Boas 1886: 132, 217, pl. 6 fig. 95g (partim, non Rang); Rampal 2002: 214 (partim, non Rang).

Cuvierina columnella (Rang, 1827) forma columnella (Rang, 1827) - Van der Spoel 1967: 79 (partim, non Rang);Van der Spoel 1970: 120, fig. 19 (partim, non Rang). Cuvierina (Cuvierina) pacifica Janssen, 2005: 46 figs. 18-20 (partim, northern Pacific specimens only, non figs. $14-17=$ C. pacifica) .

Cuvierina pacifica N (Janssen, 2005): Burridge et al. 2015: 5, fig. 2.

Holotype. RMNH.5004167, also see Fig. 1A and Table 1.

Type locality. $8^{\circ} 47^{\prime} \mathrm{N}, 158^{\circ} 49^{\prime} \mathrm{W}$.

Paratypes. See Fig. 1B-I and Table 1 for all specimen information. Three specimens from the type locality (RMNH.5004168); three specimens from the Zoological Museum of the University of Copenhagen, Denmark (ZMUC, not registered) illustrated by Janssen (2005, figs. 18-20); five specimens from four locations (RMNH.5004169-72) studied by Burridge et al. (2015, referred to as C. pacifica $\mathrm{N}$ therein). The latter five specimens have COI mtDNA and 28S rDNA sequences available at GenBank (see Table 1).

Additional material examined. Specimens recorded as C. pacifica from the North Pacific Ocean in Janssen (2005: 49, 71), housed in the Muséum National d'Histoire Naturelle (MNHN, Paris, France) and ZMUC (Copenhagen, Denmark). Specimens from Burridge et al. (2015), referred to as $C$. pacifica $\mathrm{N}$ in Table $S 1$ therein, with photographs deposited at the Dryad repository (http://dx.doi.org/10.5061/dryad.7n1q4) and COI mtDNA (KP292730-72) and 28S rDNA sequences (KP292636-42) deposited at GenBank. These specimens are housed in Naturalis Biodiversity Center (Leiden, The Netherlands) and ZMUC (Copenhagen, Denmark). Registration numbers, if available, from Janssen (2005).

Diagnosis. Shell moderately small, adult specimens $7.2-8.8 \mathrm{~mm}$ high, height/ width-ratio $2.77-3.46$ (mean 3.14), position of maximum shell width $33-42 \%$ (mean $37 \%$ ) of shell height from septum upwards. Aperture triangular. No longitudinal micro-ornamentation. 


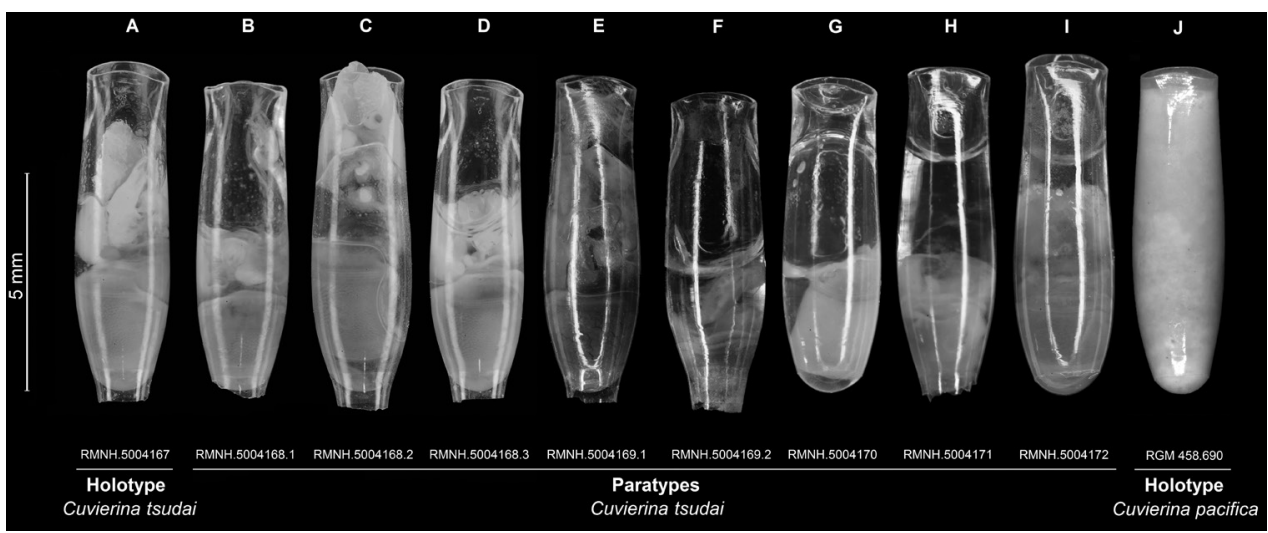

Figure I. Holotype and paratypes of $C$. tsudai and holotype of C. pacifica. A Holotype (RMNH.5004167) and B-I paratypes (RMNH.5004168-72) of C. tsudai and J holotype of C. pacifica (RGM 458.690) photographed in a ventral view. Photographs of RMNH.5004169-72 from Burridge et al. (2015); RMNH.5004167-68 taken by R. van der Hulst and RGM 458.692 taken by E.F. de Vogel, this study. $\mathrm{RMNH}=$ Naturalis Biodiversity Center, mollusc collection and RGM = Naturalis Biodiversity Center, fossil planktonic mollusc collection, Leiden.

Description. The shell shape of Cuvierina tsudai differs from other Cuvierina species. Its shell height is smaller than in C. columnella, C. cancapae, and C. atlantica, but larger than in C. urceolaris, and of similar size compared to C. pacifica. The position of maximum shell width is distinctly higher than for C. columnella and C. atlantica and lower than for C. pacifica. It is more cylindrical in shape than the inflated (bottleshaped) C. urceolaris but less cylindrical than $C$. atlantica and C. pacifica. It differs from $C$. urceolaris and $C$. cancapae by the absence of micro-ornamentation. It has a more triangular and wider aperture than $C$. urceolaris and C. pacifica (Fig. 3, Janssen 2005, Burridge et al. 2015).

Distribution. Cuvierina tsudai has a wide, exclusively Pacific distribution between $36^{\circ} \mathrm{N}$ and $39^{\circ} \mathrm{S}$, in which it co-exists with C. columnella, C. urceolaris, and C. pacifica. It has been found most often in the North Pacific, but also occurs in the South Pacific. It has not been found thus far in the central, oligotrophic parts of the South Pacific subtropical gyre, the southeast Pacific, the coral triangle west of the Philippines or southwest of Papua New Guinea.

Etymology. Named after Atsushi Tsuda, professor in biological oceanography at the University of Tokyo, Japan, for sending us pteropod samples from the Pacific Ocean and in recognition of his services to the zooplankton research community.

\section{Rejection of the subgenera in Cuvierina}

Two subgenera of Cuvierina were described that supposedly evolved since the early Miocene (Aquitanian, 23 million years ago): Cuvierina s. str., with extant species $C$. 


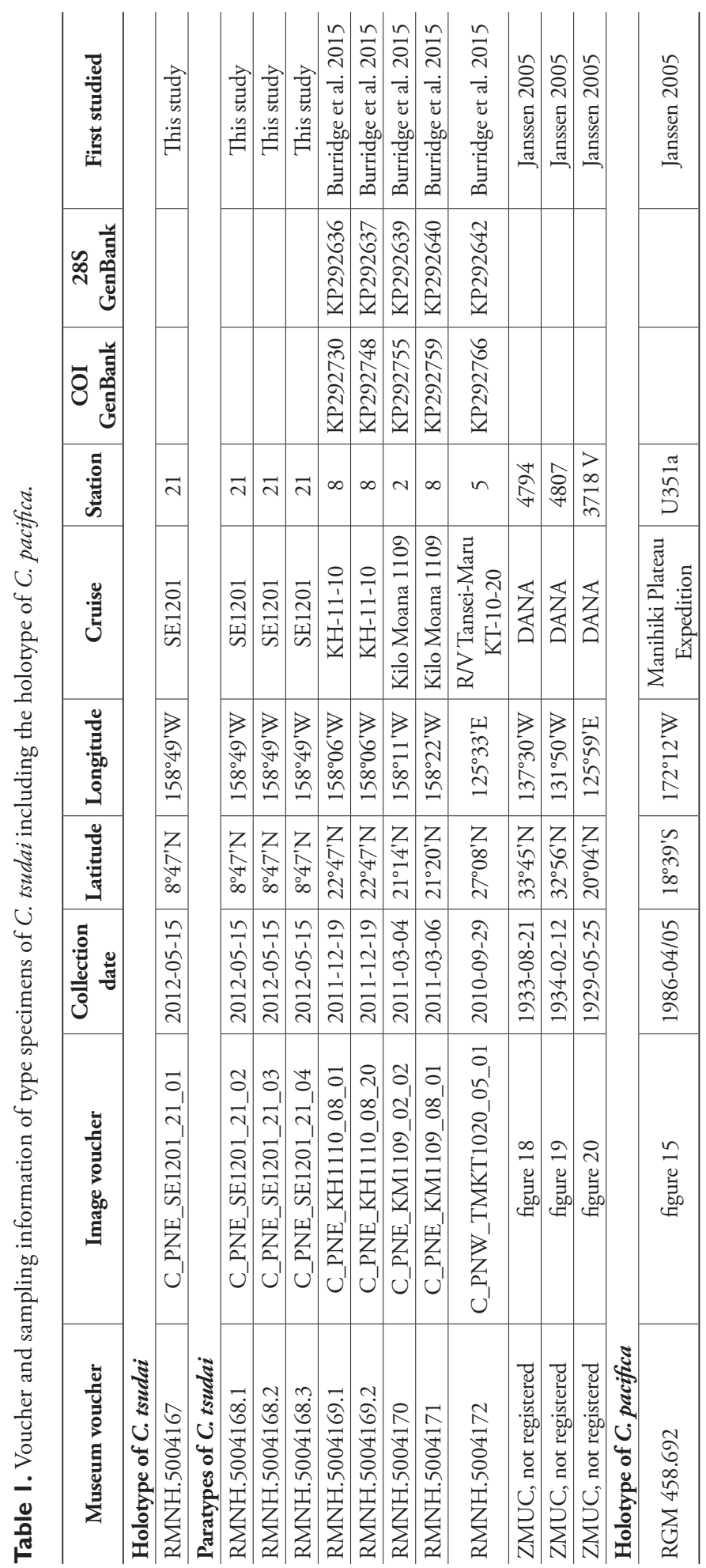






Figure 2. Shape variation in C. tsudai and C. pacifica by means of Relative Warp (RW) data. Ordination of RW data of $C$. tsudai and C. pacifica for the first ventral and apertural RWs ( $\mathrm{N}=167$ excluding 1 specimen with only one orientation). On the X-axis, RW1 depicts $78.26 \%$ of the total ventral shape variation. On the Y-axis, $69.43 \%$ of the apertural shape variation is explained by its RW1. Shape variations depicted by ventral and apertural RW1 (with subsequent RWs =0) are shown.

atlantica, C. columnella, and C. pacifica, and Urceolarica with extant species C. cancapae and C. urceolaris (see Janssen 2005, 2006). They were based on distinguishing shell characteristics in fossil species such as the position of maximum shell width, aperture shape and presence or absence of micro-ornamentation. However, the morphology and molecular phylogenetic information of recent species are in conflict with this separation. Cuvierina columnella, typically a Cuvierina s. str. species, has distinct micro-ornamentation, which was considered one of the distinguishing characters of the subgenus Urceolarica. It was shown that there are three divergent and well-supported lineages based on genetic data: the Atlantic (C. atlantica and C. cancapae), Indo-Pacific (C. columnella, C. urceolaris and C. tsudai), and South Pacific (C. pacifica) lineages (fig. 4 in Burridge et al. 2015). Hence, we reject the two subgenera within Cuvierina. 


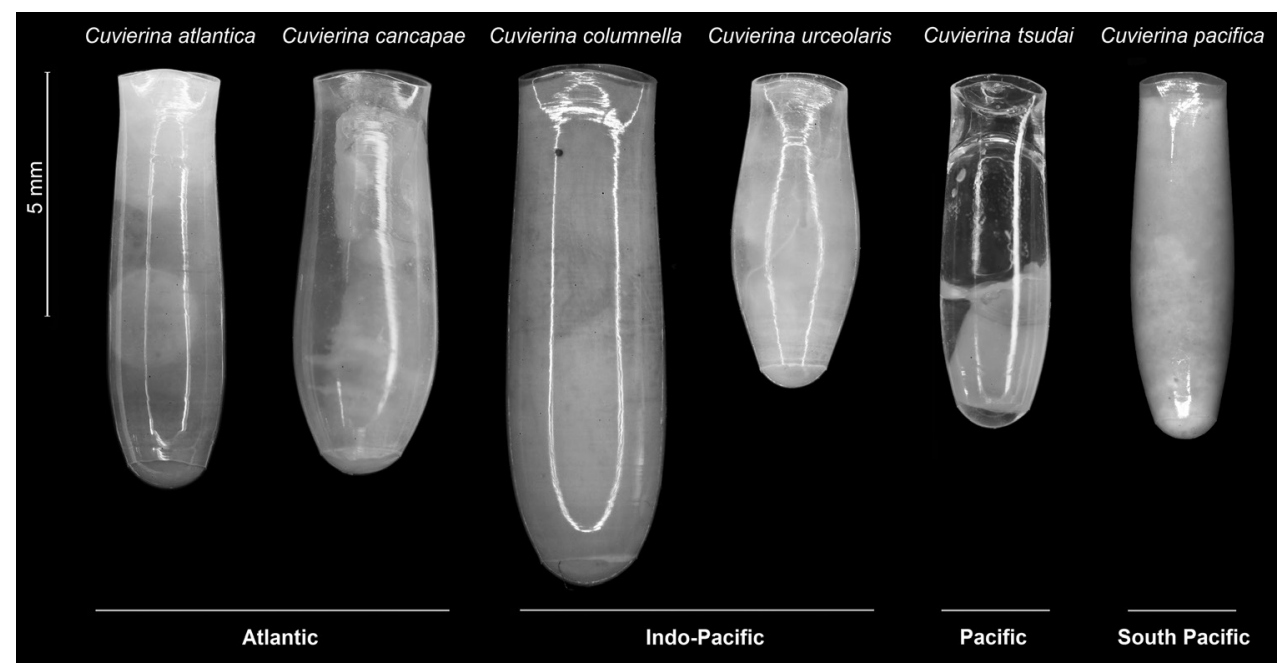

Figure 3. Typical specimens of six Cuvierina species.

\section{Taxonomic key to Cuvierina pteropods}

The following taxonomic key identifies adult Cuvierina pteropod species based on distinctive shell shape characteristics and shell sizes. Photographs of typical adult shells are shown in Fig. 3.

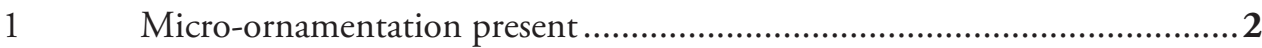

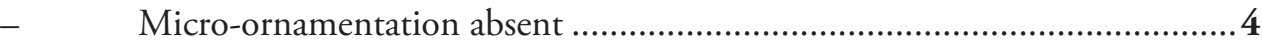

2 Strongly inflated shell shape, shell height $5.1-6.7 \mathrm{~mm}$.............. C. urceolaris

- $\quad$ Moderately inflated or cylindrical shell shape, shell height 7.5-11.1 mm....3

3 Cylindrical shell shape, shell height $8.8-11.1 \mathrm{~mm}$.................... c. columnella

- $\quad$ Moderately inflated shell shape, shell height 7.5-9.3 mm ......... C. cancapae

4 Cylindrical shell shape and triangular aperture, shell height $6.7-10.5 \mathrm{~mm}$....

C. atlantica

- Moderately inflated or cylindrical shell shape, triangular to kidney-shaped aperture, shell height $6.6-8.8 \mathrm{~mm}$....................................................... 5

5 Cylindrical shell shape and kidney-shaped aperture, shell height $6.6-8.5 \mathrm{~mm}$....

C. pacifica

- $\quad$ Moderately inflated shell shape and triangular aperture, shell height 7.2$8.8 \mathrm{~mm}$

C. tsudai

\section{Conclusions}

Morphometric, genetic, and biogeographic information has led to the introduction of a new species of the warm water pteropod genus Cuvierina and the rejection of its 
subgenera. We encourage a combined evidence approach of taxonomy to more accurately identify species boundaries and higher taxonomic relationships in planktonic gastropods. Accurate taxonomic identification is a prerequisite to assess to what extent species are affected by ocean changes and to potentially use them as bioindicators.

\section{Acknowledgements}

We thank A. Tsuda, H. Miyamoto, E. Goetze, D. Kobayashi, L. Giuseff, and E. Norton for contributing specimens from the Pacific Ocean, R. van der Hulst and E.F. de Vogel for photographing the holotype and some paratypes of C. tsudai, and J. Goud and B. van der Bijl for adding the type material to the collections of Naturalis Biodiversity Center. Finally, we are grateful to Deborah Wall-Palmer, Maria Moreno-Alcántara and Nathalie Yonow for constructive comments on this manuscript.

\section{References}

Bé AWH, MacClintock C, Currie DC (1972) Helical shell structure and growth of the pteropod Cuvierina columnella (Rang) (Mollusca, Gastropoda). Biomineralization Research Reports 4: 47-79.

Bé AWH, Gilmer RW (1977) A zoogeographic and taxonomic review of euthecosomatous Pteropoda. In: Ramsay ATS (Ed.) Oceanic Micropaleontology 1. Academic Press, London, 733808.

Bednaršek N, Možina J, Vogt M, O'Brien C, Tarling GA (2012) The global distribution of pteropods and their contribution to carbonate and carbon biomass in the modern ocean. Earth System Science Data 4: 167-186. doi: 10.5194/essd-4-167-2012

Bednaršek N, Ohman MD (2015) Changes in pteropod distributions and shell dissolution across a frontal system in the California Current System. Marine Ecology Progress Series 523: 93-103. doi: 10.3354/meps11199

Boas JEV (1886) Spolia atlantica. Bidrag til Pteropodernes. Morfologi og Systematik samt til Kundskaben om deres geografiske Udbredelse. Videnskabernes Selskap Skrifter 6. Naturvidenskabelig og mathematisk Afdeling 4(1): 1-231.

Burridge AK, Goetze E, Raes N, Huisman J, Peijnenburg KTCA (2015) Global biogeography and evolution of Cuvierina pteropods. BMC Evolutionary Biology 15: 39. doi: 10.1186/ s12862-015-0310-8 [Additional data available at doi: 10.5061/dryad.7n1q4]

Burridge AK, Goetze E, Wall-Palmer D, Le Double SL, Huisman J, Peijnenburg KTCA (2016) Diversity and abundance of pteropods and heteropods along a latitudinal gradient across the Atlantic Ocean. Progress in Oceanography 65: 414-432. doi: 10.1016/j.pocean.2016.08.003

Fabry VJ, Seibel BA, Feely RA, Orr JC (2008) Impacts of ocean acidification on marine fauna and ecosystem processes. ICES Journal of Marine Science 65: 414-432. doi: 10.1093/ icesjms/fsn048 
Gattuso J-P, Magnan A, Billé R, Cheung WWL, Howes EL, Joos F, Allemand D, Bopp L, Cooley SR, Eakin CM, Hoegh-Guldberg O, Kelly RP, Pörtner H-O, Rogers AD, Baxter JM, Laffoley D, Osborn D, Rankovic A, Rochette J, Sumaila UR, Treyer S, Turley C (2015) Contrasting futures for ocean and society from different anthropogenic $\mathrm{CO}_{2}$ emissions scenarios. Science 349: aac4722 1-10.

Gray JE (1840) Shells of molluscous animals. In: Synopsis of the contents of the British Museum, 42: 105-152.

Janssen AW (2005) Development of Cuvierinidae (Mollusca, Euthecosomata, Cavolinioidea) during the Cainozoic: a non-cladistic approach with a re-interpretation of recent taxa. Basteria 69: 25-72.

Janssen AW (2006) Notes on the systematics, morphology and biostratigraphy of fossil holoplanktonic Mollusca, 16. Some additional notes and amendments on Cuvierinidae and on classification of Thecosomata (Mollusca, Euthecosomata). Basteria 70(1-3): 67-70.

Jörger KM, Stöger I, Kano Y, Fukuda H, Knebelsberger T, Schrödl M (2010) On the origin of Acochlidia and other enigmatic euthyneuran gastropods, with implications for the systematics of Heterobranchia. BMC Evolutionary Biology 10: 323. doi: 10.1186/14712148-10-323

Kendall D (1977) The diffusion of shape. Advances in Applied Probability 9: 428-430. doi: $10.1017 /$ S0001867800028743

Lalli CM, Gilmer RW (1989) Pelagic snails: the biology of holoplanktonic gastropod molluscs. Stanford University Press, Stanford, California, 380 pp.

Lesueur CA, Petit N (1807) Voyage de découvertes aus terres Australes exécuté par ordre de S. M. l'Empereur et Roi. Langlois, Paris; atlas, part 1, 40 pls.

Meisenheimer J (1905) Pteropoda. Wissenschaftliche Ergebnisse der deutschen Tiefsee-Expedition auf dem Dampfer 'Valdivia' 1898-1899, 9, 314 pp.

Mörch OAL (1850) Catalogus conchyliorum quae reliquit C.P. Kierulf, md. dr. nunc publica auctione X Decembris MDCCCL Havniae Dividenda. Hafniae, Trieri, 33 pp. doi: 10.5962/bhl.title.39642

Moya A, Howes EL, Lacoue-Labarthe T, Forêt S, Hanna B, Medina M, Munday PL, Ong J-S, Teyssié J-L, Torda G, Watson S-A, Miller DJ, Bijma J, Gattuso J-P (2016) Near-future $\mathrm{pH}$ conditions severely impact calcification, metabolism and the nervous system in the pteropod Heliconoides inflatus. Global Change Biology. doi: 10.1111/gcb.13350

Pierrot-Bults AC, Peijnenburg KTCA (2015) Pteropods. In: Harff J, Meschede M, Petersen S, Thiede J (Eds) Encyclopedia of marine geosciences. Springer, 1-10. doi: 10.1007/97894-007-6644-0_88-1

Rampal J (1975) Les thécosomes (mollusques pélagiques). Systématique et évolution - écologie et biogéographie méditerranéennes. PhD thesis Université de Provence, U.E.R. Scientifiques (Aix-Marseille 1).

Rampal J (2002) Biodiversité et biogéographie chez les Cavoliniidae (Mollusca, Gastropoda, Opisthobranchia, Euthecosomata). Régions faunistiques marines. Zoosystema 24(2): 209-258. Rang PCAL (1827) Description de deux genres nouveaux (Cuvieria et Euribia) appartenant à la classe des ptéropodes. Annales des Sciences Naturelles 12: 320-329. [pl. 45B dated 1826] 
Rohlf FJ (2006) Tps series. http://life.bio.sunysb.edu/morph

Tesch JJ (1913) Mollusca, Pteropoda. In: Schulze FE (Ed.) Das Tierreich. Eine Zusammenstellung und Kennzeichnung der rezenten Tierformen, 36. Friedländer \& Sohn, Berlin, $154 \mathrm{pp}$.

Van der Spoel S (1967) Euthecosomata, a group with remarkable developmental stages (Gastropoda, Pteropoda), PhD thesis. University of Amsterdam, Noorduijn en Zoon, Gorinchem.

Van der Spoel S (1970) Morphometric data on Cavoliniidae, with notes on a new form of Cuvierina columnella (Rang, 1827) (Gastropoda, Pteropoda). Basteria 34: 103-151.

Van der Spoel S, Heyman RP (1983) A comparative atlas of zooplankton: biological patterns in the oceans. Springer, New York, 186 pp. doi: 10.1007/978-3-662-02366-2

Zelditch ML, Swiderski DL, Sheets HD, Fink WL (2004) Geometric morphometrics for biologists. Elsevier Academic Press, San Diego and London, 437 pp. 